\title{
Serum interleukin-18 in children with steroid sensitive nephrotic syndrome
}

\author{
Sahar Sadr Moharerpour ${ }^{\circledR}$, Azar Nickavar $^{2 *}{ }^{(\mathbb{D}}$, Simin Sadeghi Bojd $^{3}{ }^{\circledR}$, Sara Makhtomi $^{4^{\circledR}}$, \\ Hossein Ghorbani ${ }^{5}$ \\ ${ }^{1}$ Non-communicable Pediatric Disease Research Center, Health Research Institute, Babol University of Medical Sciences, Babol, Iran \\ ${ }^{2}$ Pediatric Neprology Department, Iran University of Medical Sciences, Tehran, Iran \\ ${ }^{3}$ Pediatric Neprology Department, Zahedan University Medical Sciences, Zahedan, Iran \\ ${ }^{4}$ Faculty of Medicine, Babol University of Medical Sciences, Babol, Iran \\ ${ }^{5}$ Pathology Department, Babol University of Medical Sciences, Babol, Iran
}

\section{A R T I C L E I N F O}

\section{Article Type:}

Original

\section{Article History:}

Received: 14 June 2019

Accepted: 23 August 2019

Published online: 10 September 2019

\section{Keywords:}

Nephrotic syndrome

Interleukin 18

Steroids

Urine protein

\begin{abstract}
A B S T RA C T
Introduction: Idiopathic nephrotic syndrome has been considered a cell-mediated immunity disorder with $\mathrm{T}$ cell dysfunction.

Objectives: The purpose of this study was to investigate immunologic dysfunction in children with steroid-sensitive nephrotic syndrome (SSNS) by evaluating serum interleukin-18 (IL-18). Patients and Methods: A total of 30 children with SSNS ( $\mathrm{n}=20$ males, $\mathrm{n}=10$ females), aged 1-11 years were enrolled in this study. All of them were treated with steroids at the time of study. Serum IL-18 was compared during both active and remission phases of nephrotic syndrome. In addition, correlation between serum IL-18 with urine protein and serum biochemical variables was evaluated.

Results: Mean serum IL-18 was higher in the active phase, and decreased significantly poststeroid treatment $(4.87 \pm 1.43 \mathrm{ng} / \mathrm{L}$ versus $2.39 \pm 0.94 \mathrm{ng} / \mathrm{L} ; P=0.01)$. It had no correlation with other variables.

Conclusion: According to increased serum IL-18 level, dysregulation of type-1 and type-2 mediated immune reactions is suggested in children with SSNS.
\end{abstract}

\section{Implication for health policy/practice/research/medical education:}

The role of cell mediated immunity dysfunction has been widely postulated in pathogenesis of idiopathic nephrotic syndrome. IL-18 is a proinflammatory cytokine with important regulatory effect on immune response. Identification the pathogenic effect of IL-18 in children with nephrotic syndrome is important for further diagnostic evaluations and medical management in these patients, which is discussed in this article.

Please cite this paper as: Sadr Moharerpour S, Nickavar A, Sadeghi Bojd S, Makhtomi S, Ghorbani H. Serum interleukin-18 in children with steroid sensitive nephrotic syndrome. J Renal Inj Prev. 2019; 8(4):289-291. DOI: 10.15171/jrip.2019.53.

\section{Introduction}

Interleukin-18 (IL-18), a novel immunoregulatory cytokine, is a member of IL-1 cytokine superfamily, which enhances both type-1 and type-2 mediated immune responses $(1,2)$. It plays an important role for maintaining immune system regulation (2,3). Different immunity components such as mononuclear macrophages, B cells, natural killers and other factors are responsible for synthesis and secretion of IL-18, which in turn promotes macrophages and other immunity reactions (3). IL-18 has an active role in various immunologic conditions such as infections, allograft rejection, and autoimmune disorders (4).
The pathogenesis of idiopathic nephrotic syndrome has not been completely documented. It has been proposed that cell-mediated immunity and T-cell activation, with increased lymphokine production plays an important role in mediating minimal change nephrotic syndrome (5). In addition, dysregulation of type-1/type- 2 cytokine network, with a shift to type-2 cytokine production, has been suggested in children with steroid-sensitive nephrotic syndrome (SSNS) $(1,4,6)$.

\section{Objectives}

This study was performed to evaluate the possible pathogenic role of IL 18 in children with SSNS. 


\section{Patients and Methods}

\section{Study population}

This prospective study was performed in 30 children admitted in three different children's hospitals with SSNS during 2018-2019. Individuals who fulfilled the diagnostic criteria of active nephrotic syndrome comprising massive proteinuria (more than $50 \mathrm{mg} / \mathrm{kg} / \mathrm{d}$ ), hypoalbuminemia (serum albumin below $2.5 \mathrm{~g} / \mathrm{dL}$ ), dyslipidemia and generalized edema, were contained in the investigation.

None of the individuals had clinical evidence of tubulointerstitial injury (phosphaturia, uricosuria, glucosuria or hyposthenuria), decreased renal function or electrolyte instabilities at the time of investigation. Individuals with systemic infections, immune deficiency, metabolic disorders, history of secondary or congenital nephrotic syndrome, low C3 complement level, gross hematuria, chronic renal failure, vasculitis or acute kidney injury, history of hypertension, other inflammatory diseases, and patients younger than one or older than 8 years old at diagnosis were excluded from the study.

Corticosteroid treatment was started at the dose of 2 $\mathrm{mg} / \mathrm{kg} / \mathrm{d}$ prednisone as the first line treatment. SSNS was defined as 0 -trace urine albumin in three consecutive days, resolve of edema and serum albumin more than 2.5 $\mathrm{g} / \mathrm{dL}$ after treatment.

Serum IL-18 sample was obtained during the active phase and after remission with steroids, and stored at $-80^{\circ} \mathrm{C}$. It was measured by enzyme-linked immunosorbent assay (ELISA) kit according to the manufacturer instructions and expressed as ng/L.

Serum contents of total cholesterol, triglyceride, protein, albumin, BUN and creatinine were measured by the automatic biochemistry analyzer.

\section{Ethical issue}

The research followed the tenets of the Declaration of Helsinki. The ethical committee of Babol University of Medical Sciences (ethical code; IR.MUBABOL. HRI.REC.1397.301) approved the study. The informed consents were taken from the patients. Besides, this study was extracted from M.D, thesis of Sara Makhtomi at this University (\#626).

\section{Statistical analysis}

Data were analyzed by Stata 12 (College Station, TX). Collection data were expressed by mean \pm SD. The paired samples $t$ test (dependent $t$ test) was used to compare means between two related groups, and Pearson's correlation test used to estimate the relationship between variables. $P<0.05$ was considered to indicate significance.

\section{Results}

Demographicand characteristics of the studied participants are shown in Table 1. Mean age at diagnosis was $57.6 \pm$ 28.9 (range; 12-121) months. Males outnumbered females
$(66.7 \% / 33.3 \%=2)$. None of the patients had increased blood pressure. Moreover, we showed a significant decrease of serum IL-18 level after steroid treatment in children with SSNS (Table 2). No correlation was found between serum IL-18 level with other variables, including age, urine protein and serum cholesterol.

\section{Discussion}

This study was conducted to identify alterations of serum IL-18 in children with SSNS. We found a significant increase of this cytokine in the active phase of nephrotic syndrome, which decreased with appropriate steroid treatment.

Zhou et al showed increased levels of plasma leptin, high sensitivity C-reactive protein and IL-18 in children with nephrotic syndrome compared to normal children, which obviously decreased after treatment, in accordance to the severity and prognosis of these patients (3).

In some studies, levels of IL-4, IL-13 and IL-18 were significantly higher during the active phase, compared to remission and healthy controls, with an important correlation between serum IL-18 with both IL-4 and IL-13 during all stages. They suggested a shift to type- 2 cytokine production in these patients, with a significant correlation between IL-18 expression and type-2 immune response $(1,6)$.

Serum concentration of IL-18 and IL-18 mRNA expression in peripheral blood mononuclear cells during the active phase of SSNS and steroid resistant nephrotic syndrome (SRNS) were significantly higher than those in the normal control group, and reduced after treatment in SSNS and not SRNS group. Over-production of IL-18 was suggested an important mechanism of SRNS in their study (7).

In the study by Kiliś-Pstrusińska et al, increased serum and urine IL-18 levels were observed during relapse of idiopathic nephrotic syndrome, which indicated its

Table 1. Demographic and clinical characteristics of patients

\begin{tabular}{lcc}
\hline Variables & Mean \pm SD & Range \\
\hline Age at diagnosis (month) & $57.6 \pm 28.9$ & $12-121$ \\
Calcium $(\mathrm{mg} / \mathrm{dL})$ & $8.1 \pm 0.59$ & $7.4-10$ \\
BUN $(\mathrm{mg} / \mathrm{dL})$ & $18.83 \pm 9.6$ & $9-48$ \\
Creatinine $(\mathrm{mg} / \mathrm{dL})$ & $0.5 \pm 0.1$ & $0.4-0.8$ \\
Albumin $(\mathrm{g} / \mathrm{dL})$ & $2.23 \pm 0.55$ & $1.4-4.2$ \\
Cholesterol $(\mathrm{mg} / \mathrm{dL})$ & $352.8 \pm 94.6$ & $178-616$ \\
Triglycerides $((\mathrm{mg} / \mathrm{dL})$ & $280.37 \pm 169.17$ & $50-851$ \\
24 h urine protein $(\mathrm{mg} / 24 \mathrm{~h})$ & $2437.6 \pm 1931.44$ & $1100-9384$ \\
\hline
\end{tabular}

Table 2. Serum interleukin 18 concentration in different phases of nephrotic syndrome

\begin{tabular}{lccc}
\hline Variable & Before treatment & After treatment & $\boldsymbol{P}$ \\
\hline Serum IL-18 $(\mathrm{ng} / \mathrm{L})$ & $4.87 \pm 1.43$ & $2.39 \pm 0.94$ & 0.01 \\
\hline
\end{tabular}


pathogenic role in accordance with disease activity (2). Significantly increased urinary levels of IL-18 was detected in children with minimal change nephrotic syndrome (MCNS), in correlation with the degree of proteinuria and activity of disorder in another study (8).

Matsumoto et al reported increased spontaneous and lipopolysaccharide-stimulated production of IL-18 in peripheral blood monocyte cultures of MCNS, which normalized after improvement of nephrotic syndrome. Its concentration was significantly correlated with the level of vascular permeability factor in these patients, and indicates its pathogenic role in MCNS (5).

There was a significant increase in vascular permeability factor from $\mathrm{T}$ cells following incubation with IL-18 or IL12 in other reports, which shows their synergism activity in the selective production of VPF from their T cells (9).

\section{Conclusion}

In conclusion, we provided clinical evidence that serum IL-18 might have a pathogenic role in lymphocyte dysregulation and secretion of lymphokines in children with SSNS. However, this investigation was conducted on a small proportion of patients, which makes pathologic correlation less accurate. In addition, evaluation the predictive value of serum IL-18 regarding steroid sensitivity or steroid resistance is recommended in future studies in these patients.

\section{Limitation of the study}

It is recommended to perform this study in large multicentric studies for more accurate information. In addition, comparison of serum IL 18 is suggested in two groups of patients with SSNS and SRNS for further prediction of steroid response in children with idiopathic nephrotic syndrome.

\section{Authors' contribution}

SSM collected the patients and conducted thesis. AN collected the patients, conducted thesis and was the corresponding author of the manuscript. SSb collected the patients. SM performed the thesis and HG contributed to laboratory tests.

\section{Conflicts of interest}

The authors declared no competing interests.
Ethical considerations

Ethical issues including plagiarism, double publication, and redundancy have been completely observed by the authors.

\section{Funding/Support}

This study was supported by a grant from Babol University of Medical Sciences.

\section{References}

1. Printza N, Papachristou F, Tzimouli V, Taparkou A, Kanakoudi-Tsakalidou F. IL-18 is correlated with type2 immune response in children with steroid sensitive nephrotic syndrome. Cytokine. 2008;44:262-8. doi: 10.1016/j.cyto.2008.08.012.

2. Kiliś-Pstrusińska K, Medyńska A, Zwolińska D, Wawro A. Interleukin-18 in urine and serum of children with idiopathic nephrotic syndrome. Kidney Blood Press Res. 2008;31:122-6. doi: 10.1159/000124284.

3. Zhou J, Shi F, Xun W. Leptin, hs-CRP, IL-18 and urinary protein before and after treatment of children with nephrotic syndrome. Exp Ther Med. 2018;15:4426-30. doi: 10.3892/etm.2018.5923.

4. Youssef DM, Abd Al-Atif AM, El-Khateeb SSH, Elshal AS. Evaluation of interleukin-18 in children with steroidsensitive nephrotic syndrome before and after using levamisole. Saudi J Kidney Dis Transpl. 2018;29:591-7. doi: 10.4103/1319-2442.235173.

5. Matsumoto K, Kanmatsuse K. Augmented interleukin-18 production by peripheral blood monocytes in patients with minimal-change nephrotic syndrome. Am J Nephrol. 2001;21:20-7.

6. Shalaby SA, Al-Edressi HM, El-Tarhouny SA, Fath El-Bab M, Zolaly MA. Type 1/type 2 cytokine serum levels and role of interleukin-18 in children with steroid-sensitive nephrotic syndrome. Arab J Nephrol Transplant. 2013;6:838.

7. Jiang HK, Luo G, Jiang H. Interleukin-18 expression in peripheral blood mononuclear cells in children with steroid-resistant nephrotic syndrom. Zhongguo Dang Dai Er Ke Za Zhi. 2009;11:337-40. [Chinese].

8. Matsumoto K, Kanmatsuse K. Elevated interleukin-18 levels in the urine of nephrotic patients. Nephron. 2001;88:334-9.

9. Matsumoto K, Kanmatsuse K. Interleukin-18 and interleukin-12 synergize to stimulate the production of vascular permeability factor by $\mathrm{T}$ lymphocytes in normal subjects and in patients with minimal-change nephrotic syndrome. Nephron. 2000;85:127-33.

Copyright (c) 2019 The Author(s); Published by Nickan Research Institute. This is an open-access article distributed under the terms of the Creative Commons Attribution License (http://creativecommons.org/licenses/by/4.0), which permits unrestricted use, distribution, and reproduction in any medium, provided the original work is properly cited. 